\title{
A TEACHING TOOL FOR OPERATION AND PROGRAMMING INDUSTRIAL ROBOTS KUKA
}

\section{[UCEBNA POMOCKA PRE OBSLUHU A PROGRAMOVANIE PRIEMYSELNYCH ROBOTOV KUKA]}

\author{
Ivan Fitka - Marian Kralik - Jan Vachalek - Pavol Vasek - Jan Rybar
}

doi: 10.18355/PG.2019.8.2.5

\begin{abstract}
Robotization and automation are nowadays one of the most progressive fields of education at secondary schools and universities. The implementation of these fields supports the employment of graduates on the labor market. For the purpose of education in the field of industrial robotics we have created a teaching aid that provides students simple instructions for operating and programming industrial robots KUKA with the control system KR C2.
\end{abstract}

\section{Key words}

industrial robot KUKA, manual, robot programming, robot operation, education

\section{Anotácia}

Robotizácia a automatizácia patria $\mathrm{v}$ dnešnej dobe $\mathrm{k}$ výrazne napredujúcim oborom výučby na stredných a vysokých školách. Implementácia týchto oborov podporuje uplatnenie absolventov na trhu práce. Pre potreby vzdelávania v oblasti priemyselnej robotiky sme vytvorili učebnú pomôcku, ktorá poskytuje študentom jednoduchý návod na obsluhu a programovanie priemyselných robotov KUKA s riadiacim systémom KR C2.

\section{Kl'účové slová}

priemyselný robot KUKA, manuál, programovanie robotov, obsluha robotov, vzdelávanie

\section{Úvod}

Priemyselné roboty sú $\mathrm{v}$ dnešnej dobe neodmyslitel'nou súčast'ou automatizovaných výrobných procesov. Ich využitie je predovšetkým pri manipulácii s obrobkami (paletizácia, bin picking), technológiách (zváranie, lepenie, nanášanie náterov), vizuálnej detekcii, kontrole vibrácii atd’. Obsluha, riadenie a programovanie priemyselných robotov KUKA je náročná a vyžaduje určité vedomosti z oblasti robotiky, automatizácie, elektrotechniky a programovania. ${ }^{1}$

\footnotetext{
${ }^{1}$ FIŤKA, Ivan: Vytvorenie manipulačnej úlohy pre robot KUKA. [Diplomová práca]. Slovenská technická univerzita $v$ Bratislave. Strojnícka fakulta. Ústav výrobných systémov, environmentálnej techniky a manažmentu kvality. Vedúci záverečnej práce: doc. Ing. Marián Králik, CSc. Bratislava: SjF STU BA, 2018. 183s.
} 
Slovenský trh práce ponúka pre absolventov $\mathrm{v}$ tejto oblasti viacero kvalifikovaných pracovných miest. Požiadavky zamestnávatel'ov sú ale taktiež dost' vysoké a nútia vzdelávací systém (či už na stredných alebo vysokých školách) prispôsobit’ sa dnešným potrebám. Pre účely vzdelávania a pochopenia základných princípov $\mathrm{z}$ oblasti priemyselnej robotiky so zameraním na priemyselné roboty KUKA s riadiacim systémom KR C2 sme vytvorili učebnú pomôcku (manuál, resp. návod), ktorý poskytuje teoretické aj praktické inštrukcie a návody. Učebná pomôcka bola aplikovaná ako vzdelávací prostriedok na niektorých stredných a vysokých školách na Slovensku.

\section{Tvorba učebnej pomôcky pre obsluhu a programovanie priemyselných robotov KUKA}

V dnešnej „modernej“ dobe digitálnych technológii, internetu nie je problém si zaobstarat' rôzne manuály, podklady, datasheet-y od rôznych spoločností a produktov, ktoré poskytujú a zobrazujú detailné informácie a návody $\mathrm{k}$ danému portfóliu.

V priemyselnej robotike taktiež existuje nespočetne vel'a rôznych dokumentov a návodov $\mathrm{k}$ stiahnutiu, ale nie všetky sú schopné čitatel'ovi poskytnút' prehl'adné informácie a postupy zrozumitel'ne. Predovšetkým pri programovaní priemyselných robotov to býva najčastejším problémom, kedy čitatel' neovláda základné princípy a porozumenie danej problematike mu robí bez základných poznatkov starosti. Ďalším problémom môže byt' aj samotné spracovanie manuálov od výrobcu a samozrejme aj zastaranost' a neprehl'adnost' jednotlivých postupov, príkazov, atd'.

Práve pri zastarenejšom type riadiaceho systému KR C2 sú tieto manuály spracované do podoby, kedy čitatel' bez predchádzajúcich skúseností s oblasti robotiky a automatizácie sa jednoducho nezaobíde. Práve pre tieto účely sme sa snažili vytvorit' učebnú pomôcku (návod) pre obsluhu a programovanie priemyselných robotov KUKA s riadiacim systémom KR C2. Štruktúra manuálu je tvorená postupnost'ou jednotlivých bodov, ktoré poukazujú čitatel'ovi detailné princípy a postupy z oblasti riadenia, obsluhy a samotného programovania priemyselných robotov KUKA. Pri vytváraní manuálu sme vychádzali od podkladov výrobcu, ale nakol'ko sa nám zdali byt' niektoré veci nejasné a málo rozvinuté pre pochopenie študentov, obohatili sme manuál o vlastné informácie a nadobudnuté poznatky. Hlavným ciel'om pri tvorbe manuálu bolo sprostredkovanie jednotlivých postupov, príkazov do stručnej a prehl'adnej podoby, ktorá by bola použitel'ná na stredných aj vysokých školách. Cielovou skupinou sú predovšetkým študenti ktorým má takáto pomôcka ul'ahčit' a sprostredkovat' vedomosti z oblasti priemyselnej robotiky. 


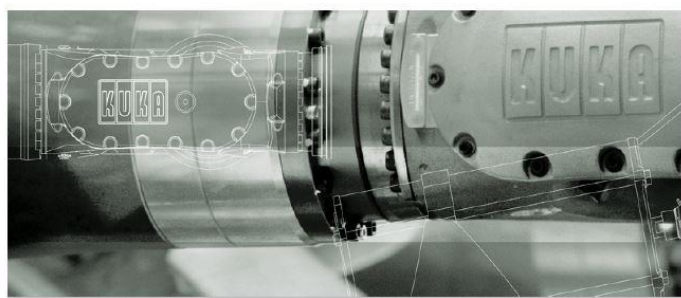

NÁVOD NA OBSLUHU A PROGRAMOVANIE ROBOTA KUKA

KR C2

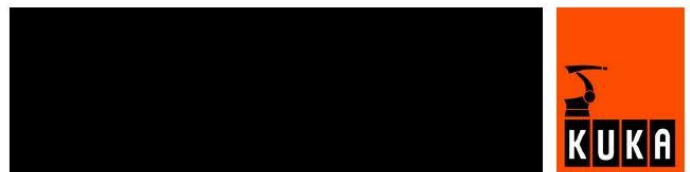

Obrázok 1: Návod na obsluhu a programovanie robota KUKA. ${ }^{2}$

2 Návod na obsluhu a programovanie robota KUKA s riadiacim systémom KR C2

Návod na obsluhu a programovanie robota KUKA sa skladá z troch hlavných kapitol, ktoré obsahujú d’alšie podkapitoly a spolu má návod 124 strán.

Prvá kapitola sa zaoberá samotným popisom priemyselného robota. V tejto kapitole sú vyobrazené a popísané hardvérové a softvérové komponenty v základnej koncepcii robotizovaného pracoviska s priemyselným robotom KUKA KR 180-2 s riadiacim systémom KR C2 (Obrázok 2).

\footnotetext{
${ }^{2}$ Vlastné spracovanie. 2019.
} 


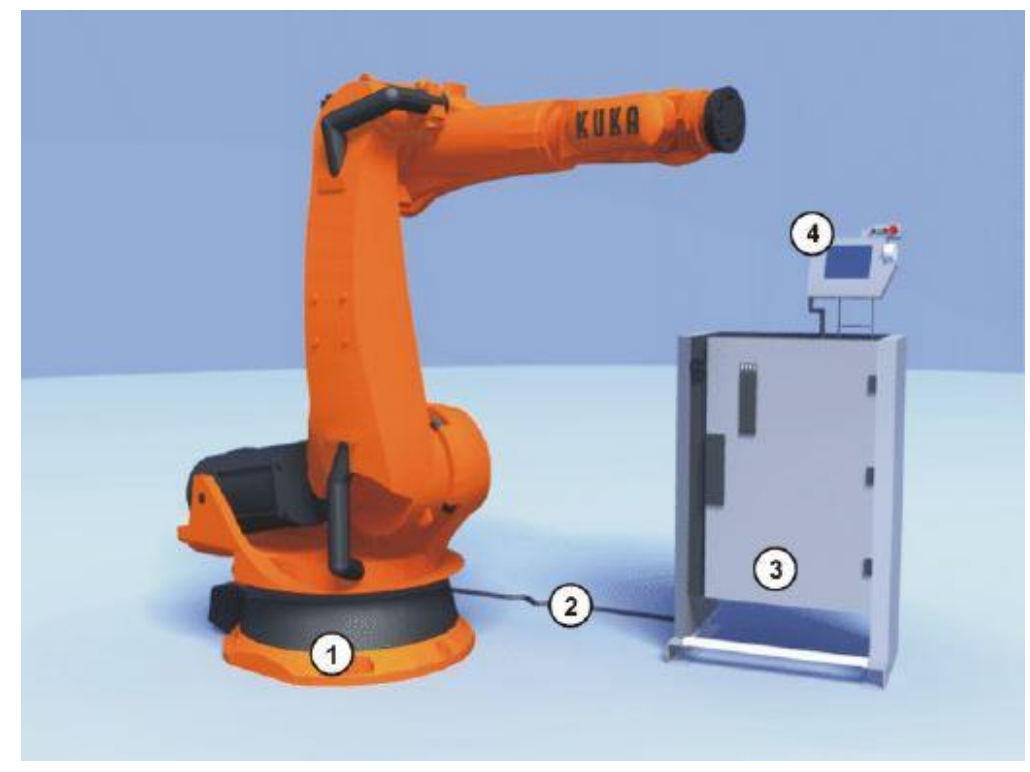

Obrázok 2: Popis priemyselného robota ( 1 - robot, 2 - vedenia, 3 - riadiaci systém KR C2, 4 -ovládací panel $K C P){ }^{3}$

Na obrázku 2 je schematicky znázornený priemyselný robot KUKA, ktorý je pomocou spojovacích vedení priamo prepojený s riadiacim systémom. Riadiaci systém je tzv. „mozgom robota” nakol'ko jeho hlavnou úlohou je predovšetkým riadenie robota s využitím informácií a vygenerovaných signálov. K riadiacemu systému je priamo pripojený ovládací panel KCP (Kuka Control Panel), ktorý nám slúži na online riadenie a programovanie priemyselného robota. ${ }^{4}$

${ }^{3}$ FIŤKA, Ivan: Vytvorenie manipulačnej úlohy pre robot KUKA. [Diplomová práca]. Slovenská technická univerzita v Bratislave. Strojnícka fakulta. Ústav výrobných systémov, environmentálnej techniky a manažmentu kvality. Vedúci záverečnej práce: doc. Ing. Marián Králik, CSc. Bratislava: SjF STU BA, 2018. 183s.

„https://www.kuka.com,“ 7.10.2010. [Online]. Dostupné: https://www.kuka.com//media/kuka-

downloads/imported/48ec812b1b2947898ac2598aff70abc0/spez_kr_c2_ed05_sk.pdf. [Cit. 15.4.2019].

„http://www.wtech.com.tw, “ 11.7.2007. [Online]. Dostupné: http://www.wtech.com.tw/public/download/manual/kuka/krc2ed05/KC2\%20Operating \%20Instruction.pdf. [Cit. 15.4.2019].

${ }^{4}$ FIŤKA, Ivan: Vytvorenie manipulačnej úlohy pre robot KUKA. [Diplomová práca]. Slovenská technická univerzita v Bratislave. Strojnícka fakulta. Ústav výrobných

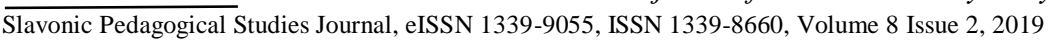


Druhá kapitola je zameraná na riadenie a obsluhu priemyselného robota KUKA. V tejto kapitole čitatel' získa informácie a postupy zamerané na spustenie robota, popis užívatel'ského rozhrania, popis súradnicových systémov, manuálny pohyb s robotom, ako sa robot uvedie do prevádzky, zameranie nástrojov a základní, atd’.

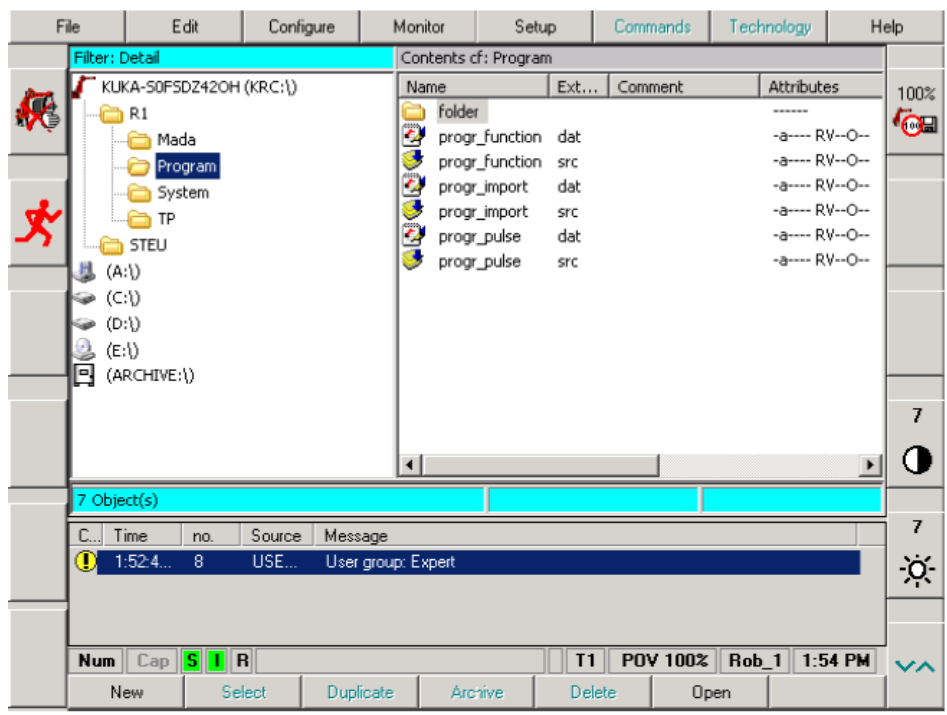

\section{Obrázok 3: Uživatel'ské rozhranie KUKA.HMI. ${ }^{5}$}

Posledná kapitola sa zaoberá samotným programovaním priemyselných robotov KUKA. Kde pod pojmom ,programovanie robotov“ môžeme chápat' vykonanie úlohy alebo operácie pomocou priemyselného robota na základe vopred naprogramovanej postupnosti bodov a logických príkazov. Jednotlivé body a príkazy sa nachádzajú vo vytvorených programoch uložených $\mathrm{v}$

systémov, environmentálnej techniky a manažmentu kvality. Vedúci záverečnej práce: doc. Ing. Marián Králik, CSc. Bratislava: SjF STU BA, 2018. 183s.

„https://www.kuka.com,“ 7.10.2010. [Online]. Dostupné: https://www.kuka.com//media/kuka-

downloads/imported/48ec812b1b2947898ac2598aff70abc0/spez_kr_c2_ed05_sk.pdf. [Cit. 15.4.2019].

„http://www.wtech.com.tw, “ 11.7.2007. [Online]. Dostupné: http://www.wtech.com.tw/public/download/manual/kuka/krc2ed05/KC2\%20Operating \%20Instruction.pdf. [Cit. 15.4.2019].

${ }^{5}$ FIŤKA, Ivan: Vytvorenie manipulačnej úlohy pre robot KUKA. [Diplomová práca]. Slovenská technická univerzita v Bratislave. Strojnicka fakulta. Ústav výrobných systémov, environmentálnej techniky a manažmentu kvality. Vedúci záverečnej práce: doc. Ing. Marián Králik, CSc. Bratislava: SjF STU BA, 2018. 183s. 
riadiacom systéme priemyselného robota. Tieto programy majú presne definovanú štruktúru a syntax.

Priemyselné roboty od firmy KUKA využívajú vlastný programovací jazyk KRL (KUKA Robot Language). Štruktúra programu KRL (Obrázok 4) je tvorená naprogramovanými pohybmi a logickými príkazmi, ktoré sa vykonávajú v postupnosti v akej boli naprogramované. Ďalej sú vysvetlené jednotlivé inštrukcie pri programovaní pohybov a logických inštrukcií, porovnanie online a offline programovania atd'.

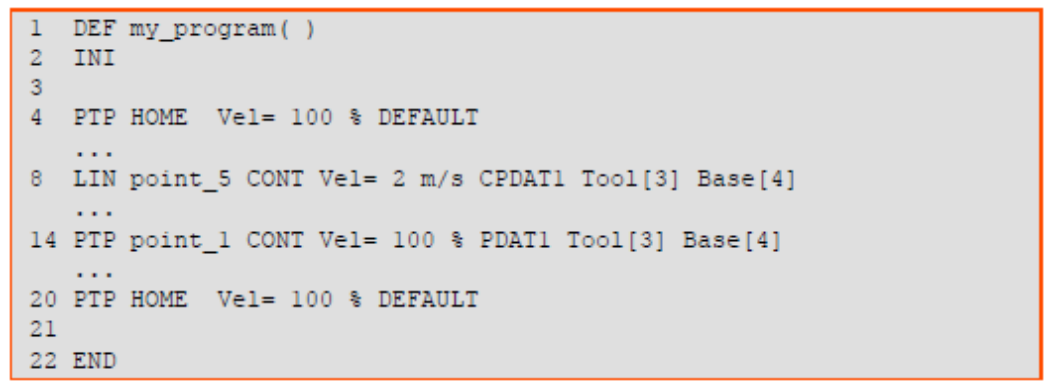

Obrázok 4: Štruktúra programu KRL. ${ }^{6}$

\section{Záver}

Ako bolo už spomenuté v úvode tohto článku robotizácia a automatizácia patria medzi odbory, ktoré sú v dnešnej dobe žiadané, či už z hl'adiska zamestnávatel'ov alebo uplatnenia absolventov na trhu práce po skončení štúdia. Základné, ale aj pokročilé vedomosti z tejto oblasti už musia študenti získat' počas procesu vzdelávania na stredných aj vysokých školách. Z tohto dôvodu sme sa rozhodli vytvorit' učebnú pomôcku, ktorá bude študentom slúžit' pre pochopenie a vysvetlenie detailných princípov s oblasti priemyselnej robotiky zameranej na roboty KUKA s riadiacim systémom KR C2. Tento vytvorený manuál (návod) sme poskytli študentom na viacerých stredných školách, ale aj vysokých školách a dúfajme že týmto sme prispeli $\mathrm{k}$ lepšiemu pochopeniu tejto problematiky.

${ }^{6}$ FIŤKA, Ivan: Vytvorenie manipulačnej úlohy pre robot KUKA. [Diplomová práca]. Slovenská technická univerzita v Bratislave. Strojnícka fakulta. Ústav výrobných systémov, environmentálnej techniky a manažmentu kvality. Vedúci záverečnej práce: doc. Ing. Marián Králik, CSc. Bratislava: SjF STU BA, 2018. 183 s. „http://www.wtech.com.tw, “ 11.7.2007. [Online]. Dostupné: http://www.wtech.com.tw/public/download/manual/kuka/krc2ed05/KC2\%20Operating \%20Instruction.pdf. [Cit. 15.4.2019].

Slavonic Pedagogical Studies Journal, eISSN 1339-9055, ISSN 1339-8660, Volume 8 Issue 2, 2019 


\section{Pod'akovanie}

Autori d’akujú Strojníckej fakulte Slovenskej technickej univerzite v Bratislave, grantovej agentúre APVV projekty (15-0295 a 15-0164); agentúre VEGA projekty číslo (1/0098/18, 1/0556/18 a 1/0610/17) a agentúre KEGA projekty číslo (006/STU-4/2018 a 039STU-4/2017) za ich podporu pri písaní tohto príspevku.

\section{Bibliographic references}

Available online:

„http://www.wtech.com.tw,“

11.7.2007.

http://www.wtech.com.tw/public/download/manual/kuka/krc2ed05/KC2\%20

Operating\%20Instruction.pdf. [Cit. 15.4.2019].

„https://www.kuka.com,“ 7.10.2010. https://www.kuka.com/-/media/kukadownloads/imported/48ec812b1b2947898ac2598aff70abc0/spez_kr_c2_ed05 _sk.pdf. [Cit. 15.4.2019].

FITKA, I. 2018. Vytvorenie manipulacnej ulohy pre robot KUKA. [Diplomova praca]. Slovenska technicka univerzita v Bratislave. Strojnicka fakulta. Ustav vyrobnych systemov, environmentalnej techniky a manazmentu kvality. Veduci zaverecnej prace: doc. Ing. Marian Kralik, CSc. Bratislava: SjF STU BA. 183 p.

Ing. Ivan Fit'ka

Institute of Automation, Measurement and Applied Informatics

Faculty of Mechanical Engineering

Slovak University of Technology

Nám. slobody 17

81231 Bratislava

Slovak Republic

ivan.fitka@stuba.sk

doc. Ing. Marián Králik. CSc.

Institute of manufactoring systems, environmental technology and quality

management

Faculty of Mechanical Engineering

Slovak University of Technology

Nám. slobody 17

81231 Bratislava

Slovak Republic

marian.kralik@stuba.sk

doc. Ing. Ján Vachálek, PhD.

Institute of Automation, Measurement and Applied Informatics

Faculty of Mechanical Engineering

Slovak University of Technology

Nám. slobody 17

81231 Bratislava

Slovak Republic 
jan.vachalek@stuba.sk

Ing. Pavol Vašek

Institute of Automation, Measurement and Applied Informatics

Faculty of Mechanical Engineering

Slovak University of Technology

Nám. slobody 17

81231 Bratislava

Slovak Republic

pavol.vasek@stuba.sk

Mgr. Ing. Ján Rybář

Institute of Automation, Measurement and Applied Informatics

Faculty of Mechanical Engineering

Slovak University of Technology

Nám. slobody 17

81231 Bratislava

Slovak Republic

jan.rybar@stuba.sk 